\title{
sciendo
}

DOI 10.2478/sbe-2020-0056

SBE no. 15(3) 2020

\section{ANALYSIS ON THE EFFECTS OF QUALITY OF FINANCIAL STATEMENTS, OVER GDP FORECASTING MODELS. AN EMPIRICAL CROSS-COUNTRY APPROACH}

\author{
BURCA VALENTIN \\ West University of Timisoara, Romania \\ MATES DOREL \\ West University of Timisoara, Romania \\ BOGDAN OANA \\ West University of Timisoara, Romania
}

\begin{abstract}
:
Under increasing macroeconomic uncertainty, governments base their economic policies on high-precision GDP estimates. The models considered based on building-up government budgets incorporate main drivers of economic growth, identified along a large range of empirical studies, mostly focused on economic productivity, factor accumulation, human capital, innovation and transfer of technology, structural changes, or institutional framework. However, there is little evidence related to the impact of accounting and assurance regulation on economic growth. Our study attempts to assess the significance of causal relation between forecasting error on GDP growth and quality of accounting standards, respectively quality of financial statements. The study analyzes the causal relation between country level measures of quality of financial reporting, synthetized by Isidro et. al. (2019), and the measure of GDP growth estimate mean error. Our results confirm a significant impact of quality of the output of financial reporting practice, related to disclosure quality and asymmetric timeliness. The results remain similar, even after controlling for accounting convergence influence. Checking for robustness of the model, we observe the main drivers of one year ahead GDP forecast error are related to institutional framework to issue high quality standards and enforce them properly. The results emphasize once again the role of economic development and corresponding complexity of economic activities and political framework impact on accounting regulation and subsequently on macroeconomic measures.
\end{abstract}

Key words: disclosures, value relevance, timeliness, harmonization, enforcement.

\section{Introduction}

Sustainable economic growth represents an essential objective for each national government. Among the premises ensuring achievement of this objective we highlight the importance of the quality of macroeconomic estimates related to main macroeconomic 
indicators, such as GDP, inflation, unemployment, or interest rate. Based on those indicators are projected national budgets, which is considered the core tool supporting allocation of public finances and continuous monitoring on forecasting and execution.

Along the last two decades there has been paid special attention to the assessment of macroeconomic forecast errors (Elliot \& Timmermann, 2016). Based on those studies, the main conclusion is that decision on optimal allocation of public finances is inherently affected by a significant level of macroeconomic forecasts error. However, researchers' efforts focus on reducing the impact of those forecast errors, leading to solutions that imply the use of advanced data analysis and modelling techniques, such as econometrics, multivariate statistics or data mining techniques. Those researches promote in the end a mix of those models, translated into more refined forecasting strategies. Instead, there has been noticed a special attention researchers gave to improve methodologies and models behind macroeconomic forecasts, ignoring or paying too less importance on the sources of data considered for macroeconomic estimation (Clements, 2005).

An alternative source to be considered by macroeconomic professional forecasters is the information disclosed by firms through financial statements. Currently, basic source of data are the capital markets and analysts' forecasts which are publicly available, at least in case of listed firms. There are considered essential forecasting information as well derived from industry benchmarking analysis, or even from financial institutions estimates related to public finance execution and analysis on GDP decomposition.

Additional to these sources, studies such as Konchichki \& Patatoukas (2014), Lechien (2017) or Fargher \& Zhang (2020), emphasize the role of accounting earnings on explaining economic growth estimates, or even the accuracy of those estimates. As noted by Dichev \& Zhao (2019), macroeconomic estimates are highly correlated with firms' accounting earnings, especially through GDP component of NIPA. Consequently, the quality of reported accounting earnings affects indirectly GDP growth estimates. In the light of the efforts of international accounting harmonization and together with significant changes on IFRSs, there has been underlined as well that changes in accounting standards could have impacted significantly GDP growth estimates (Zaidi \& Huerta, 2014; Ozcan, 2016).

As of our knowledge, our study adds to a small number of similar studies, that analyze the association between simultaneous measures of quality of financial statements and the forecast error on economic growth estimation. Do \& Nabar (2018) have underlined the role of accounting conservatism on macroeconomic estimates. Konchichki \& Patatoukas (2014), Lechien (2017) or Fargher \& Zhang (2020) have emphasized the value relevance of financial statements on the forecast error on economic growth estimation.

The article resumes to the analysis of marginal effect of quality of financial statements, as defined by IASB conceptual framework for financial reporting. Estimating a range of econometric models, the design of our research is aimed to assess the individual influence of quality of financial statements on accuracy of economic growth forecasts and separately the effect of premises drawn up by countries' institutional framework. 
The results emphasize that financial statements could represent a significant alternative source of forecasting data that results into a reduction of forecasting errors on economic growth estimates, as long as the quality of financial statements is high. Instead, once controlled the effects of institutional framework, results show that quality on financial statements represent just a complementary source of data. Essential on improving accuracy of macroeconomic estimates are the premises provided by the strength and maturity of institutional framework and the power of economic environment, that could affect resources for better accounting standard-setting and more effective enforcement mechanisms.

The motivation behind this this study refer to the invitation Leuz \& Wysocki (2016) addressed researchers, that have outlined that currently there is a lack of studies on the area of assessing the impact of financial statements on macroeconomic indicators. Afterall, the aim of our paper is to underline how important is the quality of financial statements, having implications not only on firms' decision level, reason why accounting standardsetters and enforcement institutions have to invest resources to align accounting standards and enforcement mechanism to actual economic environment.

\section{Literature review and hypothesis development}

Assessing influence of quality of financial statements on accuracy of macroeconomic forecasts suppose first the definition of the concept of quality of financial statements. As noted by Dechow et. al. (2010), there is no unanimous definition on the concept of quality of accounting information. Instead, there is a clear separation on the objectives of financial statements, namely the valuation, respectively the stewardship. If the valuation purpose of financial statements reduces to the usefulness of accounting information for investors playing on capital markets, the need of stewardship is more oriented on measuring the dynamics on shareholders' wealth. Burlaud (2013) has raised the question of how opportune is for accounting standard setters to set up barriers related to the freedom offered to managers in terms of choice of accounting policies, in order financial statements are either value relevant or should focus on faithful representation of financial position of financial performance of reporting entity. This kind of arbitrary decision has to be considered, as long as authorities appreciate there aren't in place compensating enforcement mechanisms, like different forms of corporate governance mechanisms, or institutional controls and monitoring procedures implemented by government agencies.

Dichev et. al. (2013) have emphasized that professionals prefer to chose accounting policies for the sake of value relevance of financial information, in other words the usefulness of financial information to explain stock returns. The same orientation is visible along IASB conceptual framework, that consider essential the role of financial statements on decision-making process (CF, par. 1.2), and guide entities' stakeholders towards alternative sources that provide information related to how effective and efficient is the allocation of entities' resources (CF, 1.4-1.6). However, Nobes \& Stadler (2015) have underlined that qualitative characteristics, as defined per IASB conceptual framework, are more frequently referred into financial statements as essential on the choice for an 
accounting policy, mainly in case of changes related to measurement accounting, valid especially for big firms operating in jurisdictions that ask for higher financial transparency.

Those observations become even more important if we remind that along the last decades is has been empirically assessed a continuous deterioration of quality of accounting information, especially a decline in value relevance of earnings (Dichev \& Tang, 2008; Hail, 2013; Lev 2018). Instead, those papers underline the current trend on financial statements design, that show the objective of stewardship become more and more important, which could be perceived as consequence of persistent use of accounting earnings smoothing. Therefore, creditors take over partial control on firms' management strategic decisions, by means of constraints included on contracted debts, monitored through various debt covenants which base more on balance-sheet ratios (Christensen \& Nikolaev, 2012).

\section{Importance of quality of financial statements on economic growth estimates}

Quality of firms' disclosed financial statements determine indirect effects on GDP, through NIPA component (Dichev \& Zhao, 2019). As outlined by Bruggemann et. al. (2012), macroeconomic effects are determined as well by the implementation of IFRS, like an improvement on capital markets efficiency. Similar findings are found by Zaidi \& Huerta (2014) Ozcan (2016), or Park (2018). However, those studies just confirm a significant influence of changes in accounting figures once IFRS are adopted, without checking for economic or institutional drivers of economic growth. In other words, we highlight that those studies just reveal that we should be aware of the risk that economic growth estimates are subject to superficial changes reported on macroeconomic level, including caused simply the change in accounting policies.

The discussions around the association between accounting earnings and economic growth are recent, reason why there are only some research papers addressing this topic. Summarized, most of the papers address the problem of value relevance of accounting information on macroeconomic estimates (Konchichki \& Patatoukas, 2014a; Konchichki \& Patatoukas, 2014a; Nallareddy \& Ogneva, 2017; Lechien, 2017; Fargher \& Zhang, 2020). Additionally, there have been several papers that have analyzed the impact of accounting conservatism on macroeconomic estimates (Do \& Nabar, 2018; Gaertner et. al., 2019).

However, there are even smaller number of studies that address the impact of quality of financial statements on the accuracy of economic growth forecasts. Among them are the studies of Konchichki \& Patatoukas (2014a), Lechien (2017), Tanaka et. al. (2018),

Konchichki \& Patatoukas (2014a) emphasize that aggregate accounting earnings are relevant for nominal GDP growth estimation, especially for the one-quarter-ahead forecast horizon. At least of same importance, this study reveals that macro professional forecaster do not fully incorporate the predictive content of aggregate accounting earnings growth. Thus, macroeconomic forecasts could be improved using timely accounting earnings growth information, additional to the information available about contemporaneous GDP growth. Overall, their results confirm a positive association between future GDP growth forecast errors and aggregate accounting earnings growth, 
revealing a complementary effect additional to the effect of contemporaneous GDP data, no matter forecasting horizon analyzed.

Considering a change on research design, Konchichki \& Patatoukas (2014b) reduce their analysis to the 100 largest firms, showing that accounting profitability data aggregated have predictive content for subsequent real GDP growth. Their study reiterates the observation that accounting profitability generate an incremental contribution, additional to the effect determined by market stock returns on GDP growth forecasts. Nonetheless, the authors notice that professional macro forecasters adjust their estimates on economic growth in the direction of the predictive content of aggregate accounting profitability, with implications on the macroeconomic forecasts' accuracy. Performing a DuPont profitability analysis, the authors highlight that aggregate changes in asset turnover and profit margins influence GDP growth estimates. However, changes on expectations concerning economic growth, or economic growth forecasting error seem to be predictable based on aggregate changes in operating margin and depreciation deflated by turnover. Those elements are highly affected by discretionary accounting policy choice made by managers or by accounting standards requirements. Seem that macroeconomic forecast errors are highly influenced by lagged accounting profitability data, as macro forecasters do not incorporate fully data disclosed by financial statements on macroeconomic estimates, compared to data related to stock market returns that are timely included on those forecasts. Moreover, the results enlighten that professional macro forecasters underreact to data disclosed by financial statements compared with data publicly available for capital markets participants.

Lechien (2017) reduce its analysis on a sample of European firms. This paper reveals similar findings as Konchichki \& Patatoukas (2014b). They confirm again the incremental usefulness of accounting data on macroeconomic forecasting, which is complementary to the contribution determined by data concerning stock market returns. Also, the paper reiterates the possibility macroeconomic forecasts are improved from accuracy point of view, showing that professional macro forecasters prefer to incorporate on economic growth forecasts publicly available data for stock markets participants, neglecting some financial information.

Resuming to a sample of consensus GDP growth forecasts made by Japanese forecasters, Tanaka et. al. (2018) search for the relation between macroeconomic forecasting accuracy and firms' performance. Authors confirm that GDP growth forecasts accuracy is highly related to firms' profitability, investment efficiency and employment, especially in case of firms whose performance are cyclically sensitive to GDP growth. The paper emphasizes the effect of overreaction of forecasters on GDP growth accuracy, which is highly dependent by prior year forecast accuracy. This is the reason why along the literature is underlined the need of macroeconomic forecasts accuracy, as they represent fundamental input not only for government agencies, but they affect firms' forecasting ability as well.

Fargher \& Zhang (2020) address this topic, together with the impact of regulation on investors' protection. Their study confirms that economies with stronger levels of disclosure and enforcement regulation have a lower association between changes in aggregate earnings and errors in forecasts of GDP growth. The same study shows how 
macro forecasters underreact to changes in aggregate earnings when forecasting growth in GDP, in case of countries with lower levels of investors' protection, exactly because of a decline on trust on the quality of financial statements. Like Konchichki \& Patatoukas (2014a), the authors have controlled for the effect of national institutional framework and several leading economic indicators, in order to understand the role of aggregate accounting information compared with other indicators. Their results show that aggregate accounting earnings growth significantly predicts one-year ahead GDP growth forecast errors generating an incremental contribution to the marginal effect determined be stock market returns. Additional to prior research paper, this study search also for predictive content of professional macro forecasters estimates, showing that initial official data about economic growth are highly influenced by those expectations set-up on the economy.

As long accounting information is value relevant for decision-making process, including for valuation purpose, there will be observed implications on the level of macroeconomic indicators as well. We will proceed to test the following hypothesis:

\section{$\mathbf{H}_{1}$ : Value relevance of financial statements significantly influence economic growth forecast error.}

Related to accounting conservatism, Laurion \& Patatoukas (2016) have tested and confirmed that GDP is significantly affected by accounting conservatism, measured as news related to variation on firm return, through the NIPA component. Seem that the compensation effect of aggregating firm accounting earnings does not eliminate their conservative component, meaning that accounting conservatism extend beyond firms' asymmetric timeliness on earnings reporting. Additionally, Dichev \& Zhao (2019) have underlined a significant correlation between NIPA component of GDP and the economic growth. On those circumstances, it is essential to evaluate the impact of accounting earnings asymmetric timeliness on macroeconomic estimates.

Do \& Nabar (2018) underline that conditional conservatism determine a positive effect on economic growth, while unconditional accounting conservatism determine a negative or even insignificant impact on economic growth. Moreover, the authors explain part of the accounting conservatism by country institutional framework and cultural dimensions, emphasizing that the conservative component of accounting earnings seem to be a systematic one, visible on macroeconomic indicators as well.

Instead, Gaertner et. al. (2019) perform a separate analysis of value relevance of accounting information on economic growth estimation, by making a split between the effect of positive accounting earnings and respectively The authors show that the effect of negative changes in aggregate earnings predict future GDP growth, while positive changes do not. The main driver of those effects seems to be the accounting conservatism observed on the sample analysed. In the light of the observation stated by Ball et. al. (2019) that aggregate earnings reflect rather the behaviour of firms smoothing their earnings, Gaertner et. al. (2019) underline how important is that negative earnings should be weighted more heavily, compared with positive earnings. Similar to Do \& Nabar (2018), their study confirms that accounting conservatism as well is not a matter on firm level, but 
a more systematic issue that has implications on macroeconomic estimates as well. The next hypothesis we are going to test is the following:

$\mathbf{H}_{2}$ : Accounting conservatism significantly influence economic growth forecast error.

Nallaredy \& Ogneva (2014) point out the fact that initial estimates are based on imprecise and incomplete information as well, which lead to higher probability of future restatements on GDP growth. To figure out the shocks in economy that could be predicted using aggregate accounting earnings, they underlined that aggregate accounting dispersion seem to be a better measure to predict changes in future GDP growth. More than that, the research looks for discretionary component of aggregate accounting earnings, for better control on economic environment dynamics. Their results come to similar conclusions as Konchichki \& Patatoukas (2014a), underlining the fact that statistical agencies do not fully incorporate recent aggregate earnings information into initial GDP estimates. The results show a negative association between forecast errors determined by GD growth restatements. From this perspective we will come with an additional hypothesis to test, namely:

\section{$\mathbf{H}_{3}$ : Abnormal return significantly influence economic growth forecast error.}

As of our knowledge, there is no research paper that addressed the association between firm's financial transparency and forecasting error related to economic growth estimates. However, there are researchers that ask for such studies, including Leuz \& Wysocki (2016). Consequently, we will proceed to test the following hypothesis:

\section{$\mathbf{H}_{4}$ : Disclosure quality significantly influence economic growth forecast error.}

\section{Methodology research}

The design of the research is aimed to analyze marginal effects of qualitative characteristics of financial statements on economic growth forecasts error. For this purpose, we proceed to estimation of multiple linear regression models, that estimate the association between economic growth forecast error and some essential aggregate measure of accounting information.

\subsection{Sample selection}

Countries included on our analysis resume to a sample of countries included on Isidro et. al. (2019) analysis. As observed in Table 1, our sample consist in most part of European Union members. However, sample composition allows us to control for efforts of regional accounting harmonization, considering a dummy variable in our econometric models as well, to make a clear separation on the marginal effect on macroeconomic forecast estimates, determined by EU members, respectively non-EU members. 
Table 1. The sample of countries

\begin{tabular}{cccc}
\hline \hline Argentina & Finland & Italy & Portugal \\
Australia & France & Japan & Singapore \\
Austria & Germany & Malaysia & South Africa \\
Belgium & Greece & Mexico & Spain \\
Brazil & India & Netherlands & Sweden \\
Canada & Indonesia & New Zeeland & Switzerland \\
Chile & Ireland & Pakistan & Thailand \\
Denmark & Israel & Philippines & United Kingdom \\
& & & United States \\
\hline
\end{tabular}

Source: own projection

\subsection{Data collection}

The period considered for analysis is 2011-2018. This way we try to avoid our results to be impacted by immediate effects of the recent global financial crisis. This rationale is strengthened as well by the contradictory opinions concerning the role on this financial crisis. Some researchers consider accounting represent a central driver of the financial crisis, because of lack of insufficient guidance on use of accounting standards (Emerson et. al., 2010; Lybeck, 2012). Instead, other researchers have a more moderate position, considering that essential drivers could be considered as well the ineffective compensating controls designed to prevent noncompliance of accounting practice with financial reporting regulation (Barth \& Landsman, 2010; Bischof et. al., 2019). Additionally, we avoid partially the potential bias that could be generated by the effects of IFRS adoption, as outlined by Zaidi \& Huerta (2014), or Ozcan (2016), who confirmed IFRS adoption generate only through change on accounting policies a macroeconomic effect, by a superficial increase on economic growth.

\subsection{Variables definition}

As dependent variable, we consider the forecast error for economic growth estimates for period analyzed, as reported by IMF. Our forecast error represent a percentage measure, determined deducting from official real GDP growth the estimated GDP growth made one year ahead, es defined by relation below:

$$
\Delta_{k_{i+1}}=g_{k_{i_{\text {realized }}}}-g_{k_{i+1} \text { estimated }}
$$

As defined on Elliot \& Timmermann (2016), the root mean square is a widespread measure used to determine a mean error on the macroeconomic forecasts. In our analysis are considered both summer and fall projections published by IMF, along the period analyzed.

The relation considered to calculate our mean forecast error is described by relation below:

$$
\operatorname{RMSE}_{q}^{(-1)}=\frac{\sum_{t=2010}^{2017}\left[\left(e_{q-1}^{2}\right)_{\text {summer }}+\left(e_{q-1}^{2}\right)_{\text {fall }}\right]}{2 \cdot 8}
$$


where $\left(e_{q-1}^{2}\right)_{\text {summer }}$ is the square of forecast error related to current year, made an year ahead on the summer report, while $\left(e_{q-1}^{2}\right)_{\text {fall }}$ represent the square of forecast error related to current year, made an year ahead on the fall report. The relation considers eight years analyzed.

Table 2. Definition of variables describing quality of financial statements

\begin{tabular}{|c|l|c|}
\hline Variable & \multicolumn{1}{|c|}{ Description } & Source \\
\hline $\begin{array}{c}\text { Abnormal } \\
\text { returns }\end{array}$ & $\begin{array}{l}\text { - country aggregate measure of abnomral returns, over the } \\
\text { three-day announcement window around annual earnings } \\
\text { announcements }\end{array}$ & $\begin{array}{c}\text { Nguyen and } \\
\text { Truong (2013) }\end{array}$ \\
\hline $\begin{array}{c}\text { Abnormal } \\
\text { volumes }\end{array}$ & $\begin{array}{l}\text { announcement window around annual earnings } \\
\text { announcements; }\end{array}$ & $\begin{array}{c}\text { Nguyen and } \\
\text { Truong (2013) }\end{array}$ \\
\hline $\begin{array}{c}\text { Disclosure } \\
\text { quality }\end{array}$ & $\begin{array}{l}\text { - ClFAR index calculated, based on financial statements } \\
\text { inclusion of minimum IAS reporting requirements; }\end{array}$ & $\begin{array}{c}\text { Bushman et al. } \\
(2004)\end{array}$ \\
\hline $\begin{array}{c}\text { Asymmetric } \\
\text { timeliness }\end{array}$ & $\begin{array}{l}\text { - average country-level association between firms' earnings } \\
\text { and negative stock returns; }\end{array}$ & $\begin{array}{c}\text { Bushman and } \\
\text { Piotroski (2006) }\end{array}$ \\
\hline $\begin{array}{c}\text { Value } \\
\text { relevance }\end{array}$ & $\begin{array}{l}\text { - value relevance of net income on explaining changes in } \\
\text { market returns; }\end{array}$ & $\begin{array}{c}\text { Wulandari \& } \\
\text { Rahman (2004) }\end{array}$ \\
\hline
\end{tabular}

Source: own projection

As independent variables, we consider the measures of quality of financial statements, as sued by Isidro et. al. (2019) as well. Those figures represent aggregate measures of quality of financial statements, provided by different research papers on a country level, as described in Table 2.

Table 3. Definition of country-level institutional variables

\begin{tabular}{|c|c|c|}
\hline Variable & Description & Source \\
\hline $\begin{array}{l}\text { Accounting } \\
\text { harmonization }\end{array}$ & $\begin{array}{l}\text { - aggregate measure of the level of adoption of } \\
\text { international framework in the area of firm accounting } \\
\text { (IFRS), government accounting (IPSAS), accounting } \\
\text { education (IES) and auditing (ISA); }\end{array}$ & $\begin{array}{l}\text { calculated based on } \\
\text { IFAC (2019) status } \\
\text { report and PWC } \\
\text { (2015) status report } \\
\text { on IFRS adoption }\end{array}$ \\
\hline Globalization & $\begin{array}{l}\text { - capture the level of globalization for each country, } \\
\text { through KOG index designed as per Dreher et. al. (2008); }\end{array}$ & $\begin{array}{l}\text { KOF Swiss Economic } \\
\text { Institute database }\end{array}$ \\
\hline Economic & $\begin{array}{l}\text { - aggregate factor describing economic context, } \\
\text { incorporating country-level information about: audit } \\
\text { spending, bank money in private sector to GDP, Big4 } \\
\text { market share, domestic institutional holdings, foreign } \\
\text { institutional holdings, foreign investment to GDP, GDP, } \\
\text { information and knowledge, IPOs to GDP, listed firms to } \\
\text { population, market capitalization to GDP, number of } \\
\text { analysts, ownership concentration, politically connected } \\
\text { firms, tax compliance etc }\end{array}$ & 2019) \\
\hline Sociological & $\begin{array}{l}\text { - aggregate factor describing cultural and religious } \\
\text { context, incorporating country-level information about: } \\
\text { religion type, English proficiency, ethnic fractionalization, } \\
\text { language proximity to English, Hofstede (2001) measures, }\end{array}$ & \\
\hline
\end{tabular}




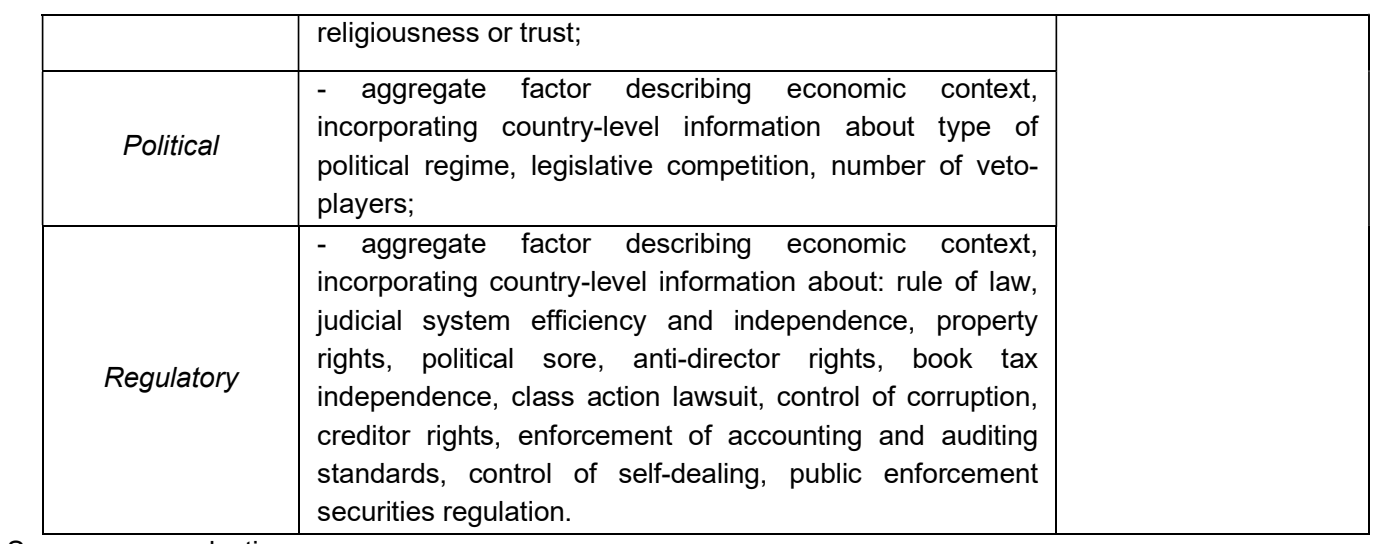

Source: own projection

To those variables, we add gradually control variables that look for the effect of countries' institutional framework and accounting harmonization as well. Summarized description is presented in Table 3. The reasons behind our rationale related to our control variables are shortly presented below:

$>$ the economic development of a country represent the premises for available resources that could be affected to finance efforts of regulatory institutions to provide high quality regulation, and to ensure proper resources for institutions to perform enforcement activities; additionally, as noted by Summyanna (2019), high level of economic development involve higher complexity of business models and institutional processes, translating into potential drivers of forecasting errors, as a consequence of lower control on economic and institution uncertainty;

$>$ cultural dimensions, religious constraints and linguistic inconsistencies, play a significant role on the design of the accounting and auditing regulation framework, especially related to Gray (1988) dimensions that concern financial transparency, accounting conservatism and uniformity firms practice on their financial reporting practice (Nobes \& Parker, 2010); those dimensions are included on the sociological factor of Isidro et. al. (2019); as long as countries are characterized by a more conservative behavior in terms of following local values and beliefs, it is expected a lower financial transparency that indirectly transmit negative signals of confidence on earnings quality; however, the effects of this factor are partly possible to be controlled through more mature and consolidated institutional enforcement environment;

$>$ political factor is considered to control the importance of current efforts of accounting deregulation that involve a higher implication of professional organizations, concomitant with reducing the impact of political decision; after all, professionals are the ones that know best the real root-cause of deficiencies that are aimed to be eliminated through regulation requirements; instead, this measure contain also information about the risk raised in the literature related to potential monopoly IASB might create on the area of accounting standard setting;

$>$ regulatory factor describes best the capacity national standard setters have the experience and expertise to issue standards that ensure a positive environment for the business, with a focus on foreign investment regulation, fight against corruption, or 
monopoles etc.; the factor incorporate as well enforcement processes and controls effectiveness on ensuring acceptable level of compliance with national regulation;

$>$ globalization process is perceived as a catalysts of all national regulation and institutional frameworks harmonization on regional and global level, reason why we expect that the risks implied by forecasting process and risks generated by accounting framework are highly transferred between countries, especially the risks specific for developed economies, imported by less developed countries;

$>$ accounting harmonization factor is aimed to measure marginal effect of regional efforts national regulation is harmonized with IFRS standards, perceived as a benchmark for high quality accounting standards.

\subsection{Econometric models}

Regression models estimated on this study measure gradually the effect of the measures of quality of financial statements, as described by models below:

$$
\begin{aligned}
& \operatorname{RMSE}_{q}^{(-1)}=\alpha_{0}+\alpha_{1} \cdot \text { Abnormal return }_{i}(\text { model } 1)^{\prime} \\
& \operatorname{RMSE}_{q}^{(-1)}=\alpha_{0}+\alpha_{1} \cdot \text { Abnormal volume }_{i}(\text { model } 2) \\
& \operatorname{RMSE}_{q}^{(-1)}=\alpha_{0}+\alpha_{1} \cdot \text { Asymetric timeliness }_{i} \quad \text { (model 3) } \\
& \operatorname{RMSE}_{q}^{(-1)}=\alpha_{0}+\alpha_{1} \cdot \text { Disclosure quality }(\text { model } 4) \\
& \operatorname{RMSE}_{q}^{(-1)}=\alpha_{0}+\alpha_{1} \cdot \text { Value relevance }_{i} \quad \text { (model 5) }
\end{aligned}
$$

where $R M S E_{i}^{(-1)}$ is the root mean square error for GDP growth estimation corresponding to country $i$.

In order to assess the effect of the perceived quality on accounting and auditing standards on macroeconomic estimate errors, in relation with country institutional attributes, we add to our econometric model Isidro et. al. (2019) measures that describe four dimensions of country institutional framework, respectively the economic environment, the regulatory power, the sociological context and the political framework. The model is described by relation below (model 6):

$$
\operatorname{RMSE}_{\bar{i}}^{(-1)}=\alpha_{0}+\sum_{n=1}^{5} \alpha_{n} \cdot \text { Quality }_{\text {accounting information }}+\sum_{n=1}^{4} \alpha_{n+4} \cdot \text { Factor }_{\text {institutional }}
$$

where Quality accounting information $_{i}$ represent each of the measures we have considered

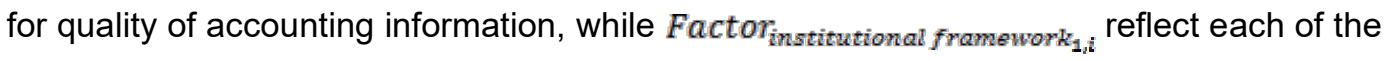
country-ralted institutional and economic factors, as calculated by Isidro et. al. (2019), related to country $i$. 
In order to check for marginal effect of harmonization in accounting, conditioned by country institutional framework effectiveness, we add to our regression model several variables, including the status on IPSAS adoption, as described below (model 7):

$$
\begin{aligned}
\text { RMSE }_{i}^{(-1)}= & \alpha_{0} \text { I } \sum_{n=1}^{5} \alpha_{n} \cdot \text { Quality }_{\text {accounting information }} \\
& +\sum_{n=1}^{4} \alpha_{n+4} \cdot \text { Factor }_{\text {institutiona }_{i}}+\alpha_{10} \cdot \text { IFR }_{i}+\alpha_{11} \cdot \text { IPSAS }_{i}
\end{aligned}
$$

where $\operatorname{IFRS}_{i}$ represent the IFRS score that reflect the level of implementation, as already described in previous section, for country $i$, according to PWC (2015) report. In the end, macroeconomic forecasts are impacted, not just by private firms' financial performance and financial position, but government institutions and state firms have high impact as well on main macroeconomic performance measures. To those variables we add also globalization score and EU membership dummy variable, in order to analyze simultaneous marginal effect of accounting harmonization score together with the framework that facilitates it, through the effect of IAS Regulation requirements and international cooperation between national standard setters.

Related to the design of our study, we have to underline the fact that factors considered on the models we estimate include just country attributes that may have an direct or indirect impact on the quality of the accounting and auditing standards, with implications on the precision of macroeconomic estimates of GDP.

The estimation of the models will be performed in SPSS 22.0, considering no fixed-effects or random-effects testing, because of small number of observations collected per country.

\section{Results and discussion}

In Table 4 we summarized the main descriptive statistics on the variables considered in estimated econometric models. Statistics point out a high mean forecast error, of approximately $1,54 \%$, meaning forecasts on economic growth made are not sufficiently accurate. In Graph 1 we observe that confirmed percentage of economic growth is close to the root mean square error. The significant gap between the mean and the maximum value of RMSE variable is explained by the outliers from our sample, which are visible in Graph 2. For Ireland we obtained the maximum value of 8.83 , while for Argentina and Brazil the mean forecast error exceeds the value of 4 , which emphasize an extremely high forecast error, generated mainly by the structure of country economic uncertainty. If in case of Ireland is well-known that public finances are exposed to a high risk of financial instruments, in case of Brazil and Argentina, the forecast error can be rather explained by high unpredictable public finance policies and lack of sustainable economic growth. 


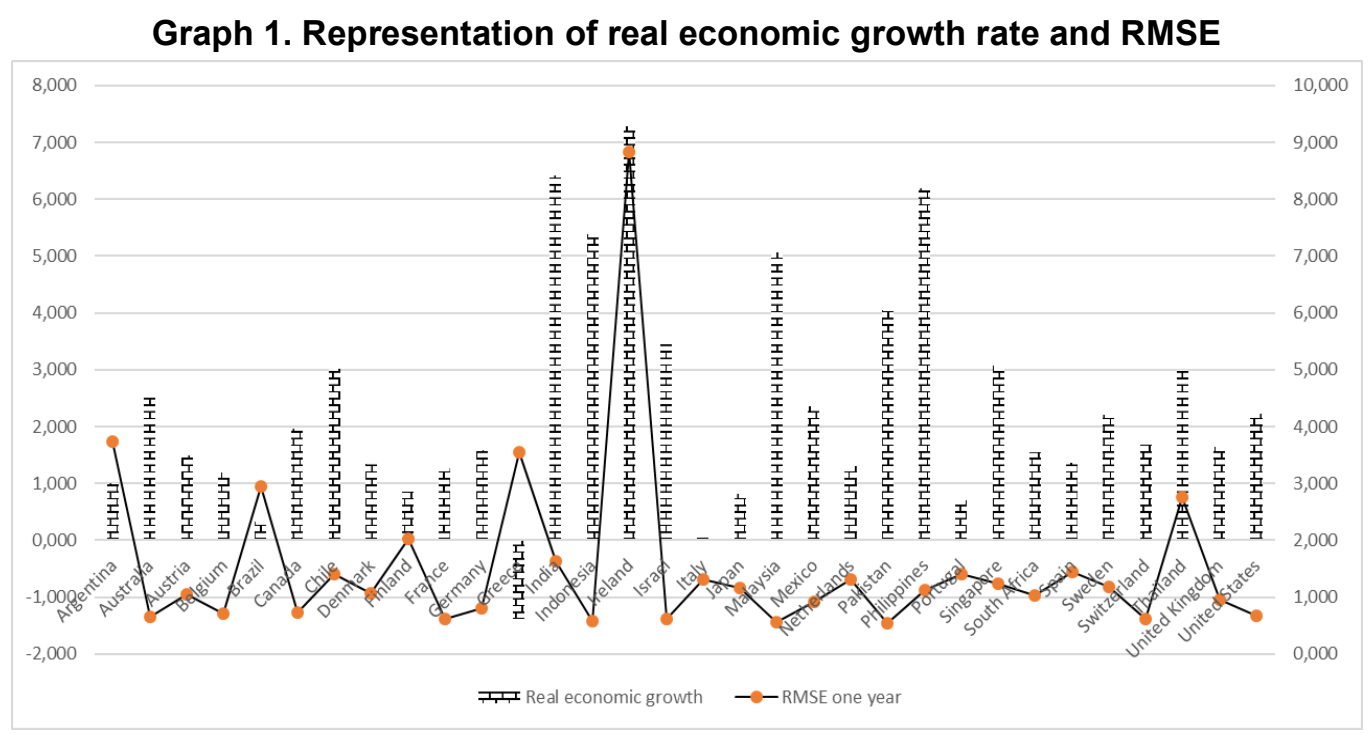

Source: own projection

Moderate mean value is reported on abnormal returns and abnormal volume, variables reflecting capital markets behavior. Similar moderate statistics are determined for asymmetric timeliness variable, which is highly connected with capital market - based variables. If either accounting regulation ask for high degree of conservatism, or managers try to avoid potential litigation costs, negative earnings are preferably reported earlier than positive earnings. With indirect implications, this behavior can have effect as well on the aggregate country level of value relevance of accounting earnings. Statistics for our sample show this effect, as value relevance has also a moderate mean value of 0.24 , which is close to the median value and about half of the maximum value of 0.55 .

Instead, we observe a high mean value of disclosure quality of about 67.56 which is extremely close to the maximum value of 85 , with a standard variation of only 19.36 . Those statistics show that financial statements are close to IASB proposed design and content of financial statements. However, this variable must be carefully analyzed, as it is based on a relatively old survey made by CIFAR on 1995. Since then, local standard setters have made progress towards harmonization with IFRS requirements, for listed companies and public interest companies IFRS becoming even mandatory on preparation of consolidated financial statements. Though, from our point of view, this is not a limit of the relevance of this variable, as it reflects a result of comparison of accounting policies included on local GAAP, which are most common with IAS/IFRS. A more serious issue of this variable is that it does not reflect entirely the quality of financial statements, as local GAAP have in most of the cases the same problems identified for IFRSs as well. One problem is the trend on proliferation of financial disclosures, additional to financial statements and included on firms' annual reports. 

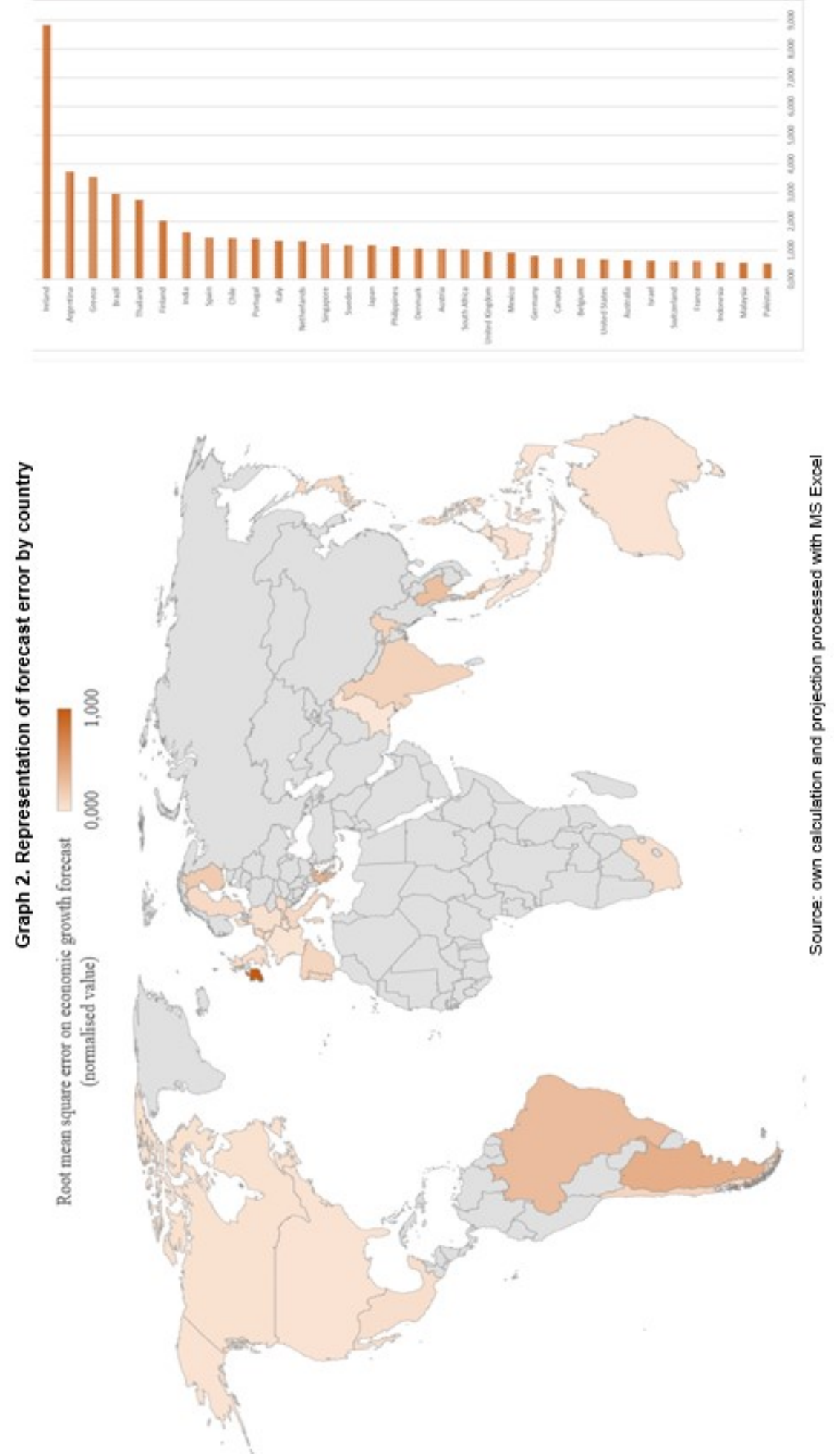
Another problem, with way higher impact on accounting information is the fact that international accounting differences persist even after IFRS are adopted globally, exactly because of higher flexibility in accounting standards (Nobes, 2015). Through more flexible financial reporting standards, managers are offered with a wider range of scenarios, when making a decision on accounting policies, implying a higher degree of discretionary decisions on this direction, in order managers increase artificially their performances and get their bonus payments. Poorly defined financial reporting requirements, alternative accepted accounting treatments, an increase in accounting estimates, highly affected by professionals' judgement, or the lack of standard accounting measurement models, lead managers to premises for discretionaryy decisions on accounting policies. This trend represents a clear effect of political factor on standard setting process, perceived because of compromise made between decision makers (Ramanna, 2015).

The differences observed in Graph 3 related to asymmetric timeliness and value relevance on a country level describe better the effect of higher flexibility in accounting standard setting. If countries with accounting systems closer to more rigid and highly detailed accounting regulation have low score on asymmetric timeliness or and value relevance, such as Austria, Germany, or Singapore, countries with accounting system closer to more principle-based accounting standards have higher score on value relevance or asymmetric timeliness, like United Kingdom, United States, Ireland or Canada.

\section{Graph 3. Representation of dimensions of quality of financial statements}

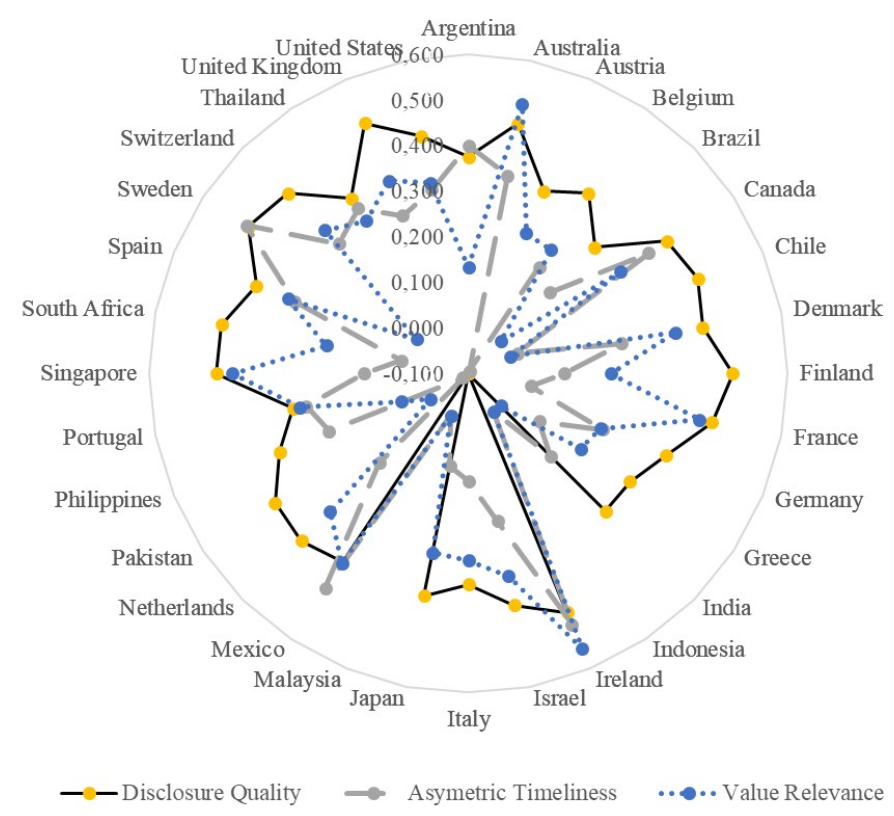

Source: own calculation processed with SPSS

Related to economic development score and the other institutional factors considered in our analysis, we highlight on Table 4 relative moderate means, compared to their median, minimum and maximum values, which means that our sample is balanced, containing high income countries and low income countries as well, countries with mature 
political system and countries with less democratic political system, or countries with consolidated enforcement institutional framework and countries with lack or poor effectiveness of enforcement institutions.

However, sociological factor considered in our analysis seem to have a negative mean of -0.139 , compared with the other similar factors, which is moderate as it is equally apart from its minimum and maximum value. Instead, this negative mean is determined by the fact that more than $50 \%$ of the countries included in our sample are described by mean a mean negative value of -0.301 , with indirect effect positive effect on forecast error. More conservative countries have more conservative accounting regulation, with less orientation towards forward-looking information that might be used even on reported accounting earnings, especially in case of interim financial reports. Countries such as Muslim ones have local GAAP which are significantly dependent on religious beliefs that, either because of requirements on the accuracy of financial reports, or just because of specific of operations that are many times limited compared to similar operations performed in capitalist countries such as UK. All these lead to more precise financial information, either we talk about capital market driven sources of information, or information disclosed by financial statements.

In Table $\mathbf{5}$ we have determined Pearson correlation measuring the strength of association between variables included on our analysis. Looking to the correlations between our dependent variables RMSE and the other variables, we observe no high correlations. However, we note that political factor, with a correlation of 0.387 , and capital market driven variables, respectively abnormal return with correlation of 0.32 , and abnormal volume with correlation of 0.35 , seem to have a higher correlation.

Similar to Nallaredy \& Ogneva (2017), shocks in economy can predict significant changes in economic growth estimates. Capitals migrate towards profitable sectors. Trends on sectors profitability is drawn up on an aggregate level by industry statistics and investors behavior on markets as well. That is why shocks in stock returns or shock on bidask spread can offer relevant information about future changes on the potential of economic growth of a country.

As mentioned, the way the due process is designed can affect significantly the output of standard setting process, because of political games played behind the scene by different decision-makers involved (Ramanna, 2015). Unless they are not involved, with real power of negotiation, as many interested parties as possible on the due process, bringing relevant accounting expertise and experience on accounting regulation, increases the risk of non-qualitative output of the standard setting process. Conclusive example is the one of IFRS adoption which seem does note solve its main scope, to eliminate international accounting differences, but rather amplify them by allowing different overt and covert options, or setting no standard on minimum requirements concerning measurement models for accounting (Nobes, 2015). One fundamental rationale behind this situation is claimed by some researchers to be cause by the fact that it has been established an IASB hegemony, supported by Big4 firms that promote IFRS adoption worldwide (Jorrisen, 2014). 
Table 4. Descriptive statistics

\begin{tabular}{|c|c|c|c|c|c|c|c|c|c|c|c|c|}
\hline & & RMSE & $\begin{array}{l}\text { KOF } \\
\text { index }\end{array}$ & $\begin{array}{l}\text { IFRS } \\
\text { index }\end{array}$ & $\begin{array}{l}\text { IPSAS } \\
\text { index }\end{array}$ & $\begin{array}{c}\text { Politi } \\
\text { cal } \\
\text { factor }\end{array}$ & $\begin{array}{c}\text { Regula } \\
\text { tory } \\
\text { factor }\end{array}$ & $\begin{array}{c}\text { Econo } \\
\text { mic } \\
\text { factor }\end{array}$ & $\begin{array}{c}\text { Socio } \\
\text { logical } \\
\text { factor }\end{array}$ & $\begin{array}{c}\text { Abnor } \\
\text { mal } \\
\text { Return }\end{array}$ & $\begin{array}{c}\text { Abnor } \\
\text { mal } \\
\text { Volume }\end{array}$ & $\begin{array}{l}\text { Asymetric } \\
\text { Timeliness }\end{array}$ \\
\hline$N$ & Valid & 32 & 32 & 32 & 30 & 32 & 32 & 32 & 32 & 32 & 32 & 32 \\
\hline Mean & & 1,540 & 68,762 & 7,656 & 1,467 & 0,080 & 0,073 & 0,065 & $-0,139$ & 4,648 & 0,717 & 0,202 \\
\hline Median & & 1,101 & 72,823 & 9,000 & 2,000 & 0,089 & $-0,022$ & 0,106 & $-0,301$ & 4,440 & 0,715 & 0,201 \\
\hline Std. Dev. & & 1,573 & 15,347 & 4,224 & 1,279 & 0,943 & 0,968 & 0,951 & 0,920 & 1,986 & 0,585 & 0,158 \\
\hline Minimum & & 0,541 & 36,880 & 0,000 & 0,000 & $-2,363$ & $-2,489$ & $-2,055$ & $-1,448$ & 0,000 & $-0,110$ & $-0,093$ \\
\hline Maximum & & 8,834 & 94,018 & 20,000 & 4,000 & 2,027 & 2,438 & 1,409 & 2,310 & 9,340 & 1,914 & 0,495 \\
\hline \multirow[t]{3}{*}{ Percentiles } & 25 & 0,692 & 57,053 & 4,250 & 0,000 & $-0,619$ & $-0,522$ & $-0,692$ & $-0,930$ & 3,583 & 0,222 & 0,092 \\
\hline & 50 & 1,101 & 72,823 & 9,000 & 2,000 & 0,089 & $-0,022$ & 0,106 & $-0,301$ & 4,440 & 0,715 & 0,201 \\
\hline & 75 & 1,436 & 80,890 & 10,000 & 2,000 & 0,540 & 0,700 & 0,752 & 0,523 & 5,523 & 1,173 & 0,314 \\
\hline
\end{tabular}

Table 5. Correlation matrix

\begin{tabular}{|c|c|c|c|c|c|c|c|c|c|c|c|}
\hline & RMSE & $\begin{array}{l}\text { KOF } \\
\text { index }\end{array}$ & $\begin{array}{l}\text { IFRS } \\
\text { index }\end{array}$ & $\begin{array}{l}\text { IPSAS } \\
\text { index }\end{array}$ & $\begin{array}{c}\text { Politi } \\
\text { cal } \\
\text { factor }\end{array}$ & $\begin{array}{c}\text { Regula } \\
\text { tory } \\
\text { factor }\end{array}$ & $\begin{array}{c}\text { Econo } \\
\text { mic } \\
\text { factor }\end{array}$ & $\begin{array}{c}\text { Socio } \\
\text { logical } \\
\text { factor }\end{array}$ & $\begin{array}{c}\text { Abnor } \\
\text { mal } \\
\text { Return }\end{array}$ & $\begin{array}{c}\text { Abnor } \\
\text { mal } \\
\text { Volume }\end{array}$ & $\begin{array}{r}\text { Asym } \\
\text { Time } \\
s \\
\end{array}$ \\
\hline KOF index & 0,042 & 1 & & & & & & & & & \\
\hline EU member & 0,192 & 0,593 & $-0,245$ & & & & & & & & \\
\hline IPSAS index & $-0,094$ & $-0,037$ & $-0,124$ & 1 & & & & & & & \\
\hline Political factor & 0,387 & $-0,105$ & 0,415 & 0,079 & 1 & & & & & & \\
\hline Sociological factor & $-0,089$ & 0,200 & 0,057 & $-0,133$ & 0,046 & 0,164 & 0,027 & 1 & & & \\
\hline$\Delta$ hnnrmal Defurn & $n 220$ & $\cap 452$ & ก 2กด & ח & ก 121 & ก 127 & ก З98 & ก 373 & 1 & & \\
\hline
\end{tabular}

Table 6. Marginal effects of quality of financial statements on GDP growth forecast accuracy

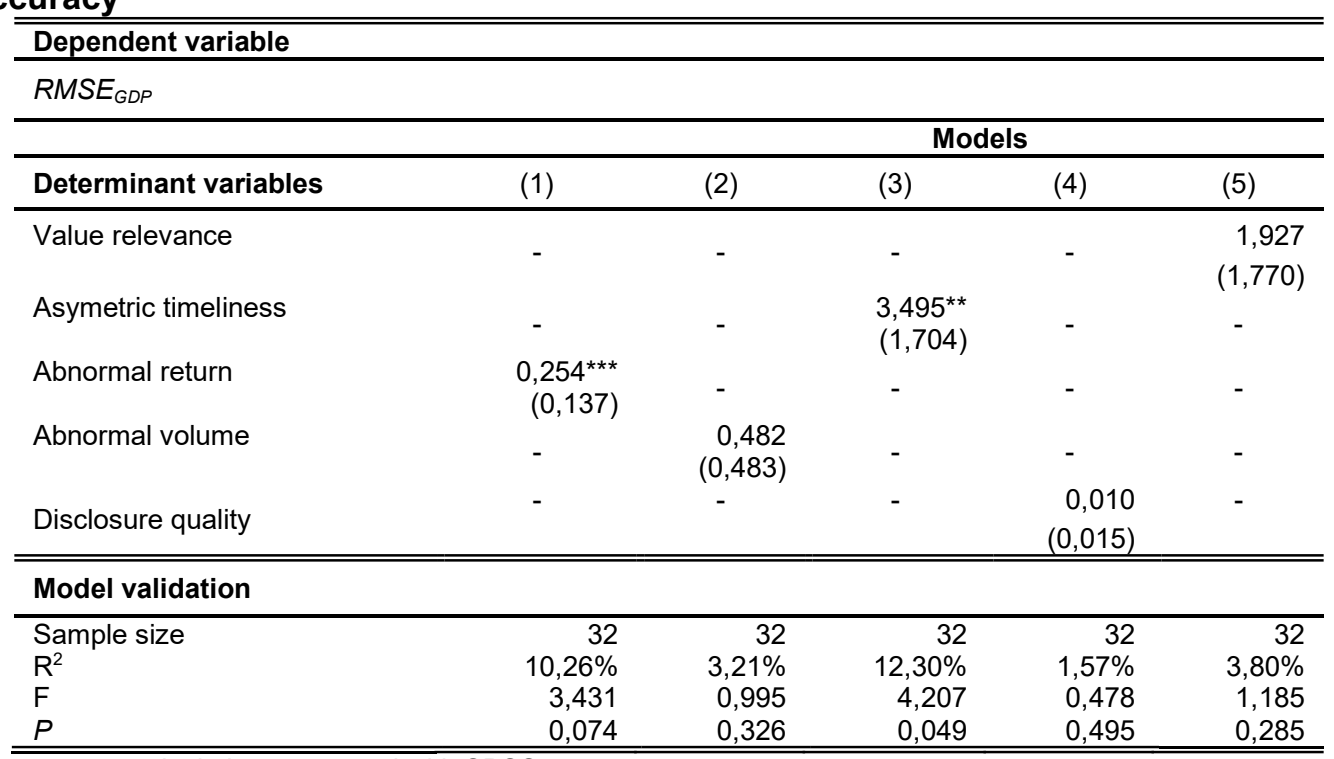

Source: own calculation processed with SPSS

However, those unfortunate effects on the quality of financial statements, are reduced partially by more mature enforcement institutional frameworks that ensure higher compliance of accounting practice with existing regulation. Christensen et. al. (2013), or Barth \& Israeli (2013) have underlined how important is that any change in accounting regulation must be correlated with proper changes in enforcement mechanisms as well. Otherwise, enforcement institutions would be unable to ensure reasonable compliance of accounting practice with local GAAP. Therefore, negative correlation between RMSE and 
regulatory factor of -0.283 reflect that forecast error on macroeconomic estimates can be reduce by simply oversighting firms to comply with existing accounting regulation. Otherwise, it is useless to have high quality accounting standards in place, but low level of compliance on practice of financial reporting.

In Table 6 we have summarized the results of individual effects determined by the measures we have selected to reflect quality of financial information, on the mean forecast error of economic growth estimates. Overall, we see that model 4 and model 5 are not statistically significant as the $p$ value exceed the acceptable significance level of $10 \%$. The other models in Table 6 are confirmed to be statistically significant.

Among those models we observe the highest value of the $R^{2}$ of $12.3 \%$ relate to model 3. However, this model explains just small part of RMSE as the value of $R^{2}$ is relatively small. This model shows marginal effect of accounting conservatism on the macroeconomic forecast error. Do \& Nabar (2018), economic growth is significantly positively associated with country conditional conservatism. Similar, Gaertner et. al. (2019) have found that economic growth rate is positively influenced by conditional conservatism, but with higher association observed in case of negative earnings. Our results are in line with the other mentioned studies, showing a positive association between asymmetric timeliness score and RMSE variable. The regression coefficient value of 3.495 represent the highest individual effect analyzed in Table 6, statistically significant with a significance level of $5 \%$. These results mean that higher the asymmetric timeliness on earnings recognition, the higher will be the forecast error on economic growth estimation. Those results have to make accounting standard setters to understand that financial statements do not have to only represent faithfully financial position and financial performance of reporting entities. At least of same importance is the value relevance of financial information as well, even more important from the perspective of macroeconomic estimation. Standard setters must understand that stewardship objective of financial statements has not be set up as primary, while value relevance of financial statements is placed on second place. Creditors must consider the same observation, in spite of results that show capital covenants (balance-sheet-based ratios) seem are not that affected by creative accounting and real activities earnings manipulation techniques as are performance covenants (profit \& loss statement-based ratios). In the recent years, there have been designed various analytical procedures and have been estimated different analytical scores that can help shareholders, creditors and the other stakeholders to get a reasonable assurance on quality of financial statements and that offer support on drawingup the state of financial health of reporting entities (Amani \& Fadlalla, 2017). On this perspective, we appreciate that more important is the position of enforcement institutions that have to make firms aware that non compliance of accounting policies with requirements of local GAAP imply high penalty costs, as capital markets anyway react proactively on signals that offer indication of manipulation of financial statements. On this perspective, local GAAP have to allow professionals to chose proper accounting policies, that assume balanced combination of accounting policies that ensure faithful representation and value relevance of financial statements as well. This balance is highly dependent by firms' specific characteristics, the economic environment they operate, or the corporate governance mechanisms implemented. As noted by Nobes \& Stadler (2015), 
most debatable accounting policies chosen by managers are the ones related to accounting measurements, which are however related to qualitative characteristics of financial information when they want to justify their choice. As long as internal controls in place are effective, firms manage properly their significant risks, or professionals are able to reflect efficiently the specific of their business model, financial statements would reach their main objectives.

Similar positive association, though with lower value, we find in model 1 that assess marginal effect of abnormal returns on RMSE. The model explains only $10.26 \%$ of RMSE, which is a relatively low value of $R^{2}$. However, the model is statistically significant as the $p$ value of 0.074 does not exceed the acceptable significance level of $10 \%$. The coefficient of 0.254 is relatively low, but statistically significant. This positive coefficient emphasize that shocks on capital markets, observed on stock returns can translate on aggregate capital markets returns, with indirect implications on economic growth estimates accuracy as well. Those results confirm, as underlined by Nallaredy \& Ogneva (2017), that shocks in economy, including shocks in capital markets, determine significant changes on economic growth as well.

Nonetheless, these results are in line with results of Patatoukas (2020) that show capital markets have a positive effect of capital markets on GDP growth forecast. After all, economic growth estimates made with one year ahead integrate more information provided by analysts' reports, rather than information disclosed by financial information. Instead, analysts' estimates are highly influenced by capital market uncertainty, which mean that higher abnormal evolutions on stock returns translate into higher economic growth forecast error.

However, we observe that value relevance of accounting information does not influence significantly the forecast error on economic growth estimates. Those results are contradictory with results of Konchichki \& Patatoukas (2014), Lechien (2017) or Fargher \& Zhang (2020), who have confirmed a significant positive association between GDP growth forecast error and accounting earnings. Instead, we must underline that our analysis refers to a measure of average of forecasting error, while those studies analyze the association between annual forecast GDP growth estimates and aggregate accounting earnings.

\section{Robustness analysis}

In Table 7, we provide results that show the effects of countries' institutional and economic framework, described by model 6 . Additional, in model 7 we assess the effect of accounting harmonization on RMSE. Overall, we see that model 7 is not statistically significant, as the $p$ value of 0.103 exceed the acceptable significance level of $10 \%$. This result highlight that efforts on accounting harmonization do not generate significant influence on economic growth estimates error. The results are explained by the fact that our analysis does not include the period of transition to IFRS adoption for most of the countries included in our sample. For instance, in case of EU members that represent the majority in our sample, IFRS were implemented before 2011, through IAS Regulation. Another reason could be the fact that global financial crisis has determined significant changes on the structure of national economies which are not significantly influenced by financial reporting framework, but rather by capital markets. However, we note that in case 
of this model the political factor significantly impacts RMSE. Statistically significant coefficient of 0.643 show that forecast error is positively affected by the way accounting standard setting due process is designed and how compromises accepted between political factors determine a decline on quality of accounting standards. After all, NIPA component represents an aggregate measure of corporate profits, that are highly determined by accounting standards, rather than by firms' specific of accounting policy. As pointed by Capkun et. al. (2012), changes in accounting regulation determined artificial changes in accounting earnings as well, changes that do not reflect dynamic on firms' operations. If those changes are frequent and do not address the essential originating issue, managers will take advantage on manipulating financial statements within the boundaries allowed by new requirements of accounting regulation.

Model 6 show exactly the impact of capital markets on economic growth forecast error, reflect by statistically significant coefficient of 0.656 . As already underlined, capital markets migrate towards industries with higher returns. Signals that show dynamics on capitals migration are mainly provided by capital markets. Once capital markets provide shocks on capital migration, those signals are integrated on analysts' estimates and indirectly on macroeconomic professional forecasters. This means that the higher the abnormal returns on capital markets, the higher is the forecast error on economic growth estimates. Abnormal returns generate a decline of aggregate stock returns, which translate into lower predictability of stock returns on economic growth. Lower the predictability of stock returns into the economic growth estimates lead to higher impact of stock returns variation on RMSE.

Table 7. Effects of quality of financial statements and institutional framework, on GDP growth forecast accuracy

\begin{tabular}{|c|c|c|c|}
\hline & \multicolumn{3}{|l|}{ Dependent variable } \\
\hline & \multicolumn{3}{|l|}{$R M S E_{G D P}$} \\
\hline & \multicolumn{3}{|c|}{ Models } \\
\hline & Determinant variables & (6) & (7) \\
\hline \multirow{7}{*}{ 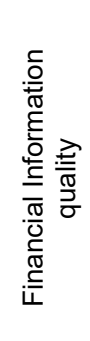 } & Value relevance & $-0,005$ & $\begin{array}{r}0,193 \\
(2315)\end{array}$ \\
\hline & Asymetric timeliness & $\begin{array}{r}(2,246) \\
1,469\end{array}$ & $\begin{array}{r}(2,010) \\
2,065\end{array}$ \\
\hline & & $(2,004)$ & $(2,103)$ \\
\hline & Abnormal return & $\begin{array}{l}0,656^{* *} \\
(0,307)\end{array}$ & $\begin{array}{l}0,587 \\
(0,34)\end{array}$ \\
\hline & Abnormal volume & $-0,149$ & $-0,388$ \\
\hline & & $(1,010)$ & $(1,109)$ \\
\hline & Diclosure quality & $-0,034^{* * *}$ & $-0,084$ \\
\hline क्ञ & Economic environment factor & $\begin{array}{r}-0,487 \\
(0,373)\end{array}$ & $\begin{array}{r}-0,112 \\
(0,592)\end{array}$ \\
\hline$\frac{\dot{\mathscr{T}}}{\frac{\pi}{\pi}}$ & Regulatory environment factor & $\begin{array}{r}-0,633^{* *} \\
(0,272)\end{array}$ & $\begin{array}{r}-0,944^{\star *} \\
(0,348)\end{array}$ \\
\hline$\stackrel{\check{c}}{\underline{0}}$ & Sociological environment factor & $\begin{array}{r}-0,416 \\
(0,326)\end{array}$ & $\begin{array}{r}0,289 \\
(0,558)\end{array}$ \\
\hline 索 & Political environment factor & 0,385 & $0,643^{\star * *}$ \\
\hline O̊ & G'ōobalization factor & $\begin{array}{l}0 \\
-\end{array}$ & $\begin{array}{r}(0,359) \\
-0,052 \\
(0,043)\end{array}$ \\
\hline 恶㐫 & EU member (dummy) & - & $\begin{array}{r}1,004 \\
(0,940)\end{array}$ \\
\hline 这 & IFRS adoption index & - & $\begin{array}{r}-0,084 \\
(0,092)\end{array}$ \\
\hline
\end{tabular}




\begin{tabular}{lrr}
\hline \hline Model validation & & \\
\hline Sample size & 33 & 33 \\
$\mathrm{R}^{2}$ & $48,88 \%$ & $61,34 \%$ \\
$\mathrm{~F}$ & 2,337 & 1,953 \\
$p$ & 0,050 & 0,103 \\
\hline \hline
\end{tabular}

Source: own calculation processed with SPSS

Significant influence on RMSE is also obtained in case of disclosure quality, as the coefficient of -0.034 lead us to the conclusion that the closer are financial statements to IFRS, perceived by investors as benchmark for high quality financial statements, the more predictable are accounting earnings and the lower is forecast error for economic growth estimation. The negative association can be also explained by the fact that IAS/IFRS adoption has determined improvements on predictability of financial statements (Bruggemann et. al., 2012; De George et. al., 2017), which lead to more representative aggregate accounting earnings used on estimating economic growth. Instead, we underline that the score of disclosure quality address only the form of presentation of accounting information. More important is the effect of accounting choice on the content presented on the financial statements. As long as accounting methods do not converge, standardization of the structure of financial statements and the way they are presented become less relevant.

As outlined previously, effectiveness of enforcement institutional framework is fundamental on ensuring reasonable compliance of accounting practice with requirements of accounting regulation. Christensen et. al. (2013) and Barth \& Israeli (2013) have emphasized that any change in accounting regulation have to be made in correlation with adjustments on enforcement mechanisms, either defined and implemented on country level by government agencies, or prescribed as mandatory for firms to implement, such as the implementation or minimum requirements concerning corporate governance. Those mechanisms determine a higher quality of financial statements as there are in place compensating controls that control and monitor continuously quality of accounting information. Noncompliance translate automatically into, either high litigation costs claimed by investors, or extremely high financial sanctions instituted by government control agencies.

Compared with models from Table 6, we observe on models in Table 7 that accounting conservatism, reflected by asymmetric timeliness score does not influence statistically anymore the forecast error of economic growth estimates. The coefficient of 1.469 from model 6 still reflect the highest marginal effect, compared with the other variables and remain positive. Instead, the results show that timeliness of accounting earnings is less relevant for macroeconomic estimates than the effect generated by the capital markets and enforcement institutional framework. Those results underline that quality of financial statements is important. However, financial statements used as source of information for macroeconomic estimations are just complementary to the main already existing sources of information. Because of the gap of timing between publishing financial statements and macroeconomic estimates, because of the increasing number of information technology tools that allow macroeconomic professional forecasters to integrate into their forecasting models huge amount of actual publicly available information, 
nowcasting models seem to become more important on the area of forecasting economic growth.

\section{Conclusions}

The role of accurate macroeconomic estimates is essential on decisions concerning public finances, reason why researchers have addressed this topic continuously along the last two decades. Major part of the papers has focused on identifying the main economic and institutional drivers that influence the accuracy of macroeconomic forecasts. There have been identified solutions to improve macroeconomic forecasts accuracy by optimizing methodology behind. Instead, there has been paid poor attention on the role of firm financial statements perceived as potential source of information for macroeconomic professional forecasters. The interest on this topic has been recently addressed by few papers. Our paper is aimed to bring to the literature additional insights on the association between quality of financial statements and the accuracy of economic growth forecasts. Our analysis is resume to the validation of research hypothesis described in Table 8.

Overall, the results show that capital markets determine a significant influence on the forecast error of economic growth estimates. Consequently, the accuracy of economic growth estimates can be improved as long as macroeconomic professional forecasts choose tools and procedure of forecasting that can incorporate timely all information publicly available, like is the case of nowcasting forecasting models more frequently used on the last years for GDP growth estimation.

Additionally, we confirm that asymmetric timeliness of accounting earnings can represent a significant driver on improving GDP growth estimates accuracy. Despite those individual effects of accounting conservatism on economic growth forecast error, seem that once controlling for country institutional and economic profile, those results are not robust. Additionally, we observe that standardization of financial statements seems to play a significant role on ensuring higher comparability and predictability of financial information, with positive implications on the accuracy of economic growth estimates accuracy.

Table 8. Conclusion concerning research hypothesis

\begin{tabular}{|c|l|c|}
\hline Hypothesis & \multicolumn{1}{|c|}{ Description } & Status \\
\hline$H_{1}$ & $\begin{array}{l}\text { Value relevance of financial statements significantly influence } \\
\text { economic growth forecast error. }\end{array}$ & Rejected \\
\hline$H_{2}$ & $\begin{array}{l}\text { Accounting conservatism significantly influence economic } \\
\text { growth forecast error. }\end{array}$ & $\begin{array}{c}\text { Accepted } \\
\text { partially }\end{array}$ \\
\hline$H_{3}$ & $\begin{array}{l}\text { Abnormal return significantly influences economic growth } \\
\text { forecast error. }\end{array}$ & Accepted \\
\hline$H_{4}$ & $\begin{array}{l}\text { Disclosure quality significantly influence economic growth } \\
\text { forecast error. }\end{array}$ & $\begin{array}{c}\text { Accepted } \\
\text { partially }\end{array}$ \\
\hline
\end{tabular}

Source: own projection

However, we conclude that the specific of country institutional framework and its effectiveness are essential, compared with quality of financial statements. On those circumstances, we reach to similar conclusion as Konchichki \& Patatoukas (2014), Lechien 
(2017) or Fargher \& Zhang (2020), who emphasized that use of aggregate accounting earnings can improve macroeconomic forecasts accuracy, but only as a complementary source of information, additional to already existing sources of financial information publicly available.

We underlined that our study has some limitations. First limitation is the small sample, as it contains only 32 countries. However, the sample is balanced, containing countries spread around the world. Another limitation is related to the fact that we have not looked for the quality of accounting standards, but just for an aggregate score describing the quality of financial statements. We must remind that quality of accounting standards does not mandatory translate into the quality of financial statements, is this association is conditioned by the maturity and effectiveness of economic and institutional enforcement activities. Nonetheless, we highlight that the design of our study is aimed to assess the association between an average measure of GDP growth forecasts and measures of quality of financial statements, which means we have not looked for time effects that could reveal relevant information about changes determined on quality of financial statements, generated by more recent reforms on the area of accounting regulation, as is the case of some EU directives, such as Directive 34 from 2013, Directive 95 from 2014, or the new IFRS standards. Such approach represents an objective for us for further research, oriented on specific areas of analysis.

\section{References}

Amani F.A., Fadlalla A.M. (2017), Data mining applications in accounting: A review of the literature and organizing framework, International Journal of Accounting Information Systems, vol. 24, p. 32-58;

Barth M.E., Israeli D. (2013), Disentangling mandatory IFRS reporting and changes in enforcement, Journal of Accounting and Economics, vol. 56, issues 2-3, Supplement 1, p. 178-188;

Barth M.E., Landsman W.R. (2010), How did Financial Reporting Contribute to the Financial Crisis?, European Accounting Review, vol. 19, issue 3, p. 399-423;

Bischof J., Laux C., Leuz C. (2019), Accounting for Financial Stability: Lessons from the Financial Crisis and Future Challenges, European Corporate Governance Institute (ECGI) - Working

Paper No. 445/2019, available on

https://papers.ssrn.com/sol3/papers.cfm?abstract id=3319542;

Bruggemann U., Hitz J.M., Selhorn T. (2012), Intended and Unintended Consequences of Mandatory IFRS Adoption: A Review of Extant Evidence and Suggestions for Future Research, European Accounting Review, vol. 22, issue 1, p. 1-37;

Christensen H.B., Hail L., Leuz C. (2013), Mandatory IFRS reporting and changes in enforcement, Journal of Accounting and Economics, vol. 56, issues 2-3, Suplement 1, p. 147-177;

Christensen H.B., Nikolaev V.V. (2012), Capital Versus Performance Covenants in Debt Contracts, Journal of Accounting Research, vol. 50, issue 1, p. 75-116;

Clements M.P. (2005), Evaluating econometric forecasts of economic and financial variables, Palgrave MacMillan, New York;

Dechow P., Gee W., Schrand C. (2010), Understanding earnings quality: A review of the proxies, their determinants and their consequences, Journal ofAccountingandEconomics, vol. 50, p. 344-401;

Dichev I.D., Graham J.R., Harvey C.R., Rajgopal S. (2013), Earnings quality: evidence from the field, Journal of Accounting and Economics, vol. 56, issue 2-3, Supplement 1, p. 1-33; 
Dichev I.D., Tang V.W. (2008), Matching and the changing properties of accounting earnings over the last 40 years, The Accounting Review, vol. 83, issue 6, p. 1425-1460;

Dichev I.D., Zhao J. (2019), Comparing GAAP With NIPA Earnings, Journal of Accounting, Auditing \& Finance, Forthcoming;

Do C., Nabar S. (2018), Macroeconomic effects of aggregate accounting conservatism: $A$ cross-country analysis, Journal of International Financia Management \& Accounting, vol. 30, issue 1, . p. 83-107;

Elliot G., Timmermann A. (2016), Economic forecasting, Princeton University Press, New Jersey;

Emerson D.J., Karim K.E., Robert W. (2010), Fair Value Accounting: A Historical Review of The Most Controversial Accounting Issue In Decades, Journal of Business \& Economics Research, vol. 8, issue 4, p. 77-85;

Fargher N., Zhang L. (2020), Investor Protection, Aggregate Accounting Earnings and Forecasts of Growth in GDP: International Evidence, working paper, available on www.ssrn.com, accessed on 08.10.2020;

Gaertner F., Steele L., Kauser A. (2019), The Usefulness of Negative Aggregate Earnings Changes in Predicting Future Gross Domestic Product Growth, Review of Accounting Studies;

Hail L. (2013), Financial reporting and firm valuation: relevance lost or relevance regained? Accounting and Business Research, vol. 43, issue 4, p. 329-358;

Isidro H., Nanda D., Wysocki P. (2019), On the Relation between Financial Reporting Quality and Country Attributes: Research Challenges and Opportunities, The Accounting Review, vol. 93, issue 6;

Konchichki Y., Patatoukas P.N. (2014a), Accounting earnings and gross domestic product, Journal of Accounting and Economics, vol. 57, p. 76-88;

Konchichki Y., Patatoukas P.N. (2014b), Taking the pulse of the real economy using financial statement analysis. Implications for Macro Forecasting and Stock Valuation, The Accounting Review, vol. 89, issue 2, p. 669-694;

Lechien G. (2017), Taking the pulse of the real economy using financial statement analysis: the european perspective, working paper available on https://run.unl.pt/bitstream/10362/36557/1/Lechien 2018.pdf, accessed on 09.02.2020;

Leuz C., Wysocki P.D. (2016), The Economics of Disclosure and Financial Reporting Regulation: Evidence and Suggestions for Future Research, Journal of Accounting Research, vol. 54, issue 2, p. 525-622;

Lev B. (2018), The deteriorating usefulness of financial report information and how to reverse it, Accounting and Business Research, vol. 48, p. 465-493;

Lybeck J.A (2012), Global history of financial crisis, Polirom, Bucharest;

Nallareddy S., Ogneva (2017), Predicting Restatements in Macroeconomic Indicators using Accounting Information, The Accounting Review, vol. 92, issue 2, p. 151-182;

Nobes (2015), International differences in IFRS adoptions and IFRS practices, included in volume The Routledge Companion to Financial Accounting Theory, Routledge, New York, p. 167-196;

Nobes C., Stadler C. (2015), The qualitative characteristics of financial information, and managers' accounting decisions: evidence from IFRS policy changes, Accounting and Business Research, vol. 45, issue 5, p. 572-601;

Nobes C.W., Parker R. (2010), Comparative International Accounting, $11^{\text {th }}$ edition, Pearson, New York;

Ozcan A. (2016), Assessing the effects of IFRS adoption on economic growth. A cross country study, ACU International Journal of Social Sciences, vol. 2, issue 2, p. 65-80;

Park Y. (2018), Accounting standards and predictive ability of aggregate accruals for economic growth, Duke University working paper, available on www.semanticscholar.org, accessed on 06.02.2020 ; 
Patatoukas P.N. (2020), Stock Market Returns and GDP News, Journal of Accounting, Auditing \& Finance, Forthcoming;

Ramanna K. (2015), Political Standards. Corporate Interest, Ideology, and Leadership in the Shaping of Accounting Rules for the Market Economy, University of Chicago Press, Chicago;

Tanaka M., Bloom N., David J.M., Koga M. (2018), Firm Performance and Macro Forecast Accuracy, working paper, https://www.nber.org/papers/w24776, accessed on 10.02.2020;

Zaidi S., Huerta E. (2014), IFRS Adoption and Enforcement as Antecedents of Economic Growth, International Journal of Accounting and Financial Reporting, vol. 4, issue 1. 